\title{
Performance of Coconut Hybrids in United Plantations Berhad and Commercial Production of Seed Nuts
}

\author{
Xaviar Arulandoo, Kandha Sritharan, and Mohan Subramaniam
}

\begin{abstract}
United Plantations Berhad began its first coconut planting in 1912. Since then, it has been the responsibility of the breeding team in its research department to sustain a high standard of plant breeding techniques in the development of future planting materials aligned with the objectives of the company. The yield performance of Tall x Tall, Dwarf x Dwarf and Dwarf $\mathrm{x}$ Tall hybrids as well as salient points in the commercial production of hybrid seed nut is highlighted.

Current plantings at UPB consist of older generation of $\mathrm{MAWA}^{+}$with average yields of 30,000 nuts per hectare per year and newer generations of MATAG* with yields comparable to MAWA but with improved nut characteristics. Breeding strategies are now in place to produce hybrids (Dwarf $\mathrm{x}$ Tall) capable of out-performing the MATAG in terms of yield and nut characteristics with minimum yields per hectare of 40,000 nuts and eight tonnes copra.

Amongst the Tall $\mathrm{x}$ Tall hybrids and pure lines of Tall, highest yields were achieved with Tagnanan followed by West African with yields of 24,190 and 23,514 nuts per hectare, respectively, adopting a planting density of 178 palms per hectare. The highest yielding Dwarf $\mathrm{x}$ Dwarf cross and self is the Aromatic Green (AGD) and CAMMA ${ }^{++}$, which provided a similar yield magnitude of 40,000 nuts per hectare planted at a density of 265 palms per hectare. However, as they had lower copra yield as dry nut and lower water content as fresh nut, Dwarf x Dwarf was not the desired commercial planting material. Hence, the breeding programme emphasized in the creation of Dwarf $\mathrm{x}$ Tall hybrids aimed at exploiting the large nut size from the tall and high nut number from the dwarf. Amongst the hybrids evaluated in UPB, MATAG hybrid though with lower nut yields had 53.9\% higher copra yields per hectare than both AGD and CAMMA making it at present the preferable choice for commercial planting. Newer hybrids are currently being evaluated which shows promise of similar nut yield but improved nut characteristics.

The commercial seednut production field is confined to a block of 25 hectares and is operated by the Research Department with a maximum production capacity of 110,000 saleable hybrid seednuts (4 months old) germinated seednuts per year. With escalation in costs of inputs and wages, the cost of seednut production has risen to RM30 per seednut in 2014. However, with good agricultural management practices complementing the superior hybrid planting materials, the production cost of a mature coconut from the plantations is relatively low, thus ensuring a sustained profitability of the coconut plantations in United Plantations Berhad.
\end{abstract}

Keywords: Coconut, Coconut Hybrids, Copra Yields, Seed Nut Productions, Economics of Coconut Seed Production, United Plantations Berhad.

\footnotetext{
Note: ${ }^{+}$refers to Malayan Dwarf x West African Tall (MAWA)

* refers to Malayan Dwarf x Tagnanan Tall (MATAG)

${ }^{++}$refers to Cameroon Red Dwarf x Malayan Dwarf (CAMMA)
}

United Plantations Berhad, 36009 Teluk Intan, Malaysia.

Email: uprd4@hotmail.com 


\section{Introduction}

The coconut palm, also known as the tree of life, is a versatile crop incorporated into the culture of various ethnicities around the world. Man has been able to utilize almost every component of the tree for his needs. Derivatives of the coconut form an essential component in the diet of many cultures. In Asia, coconut has a dominant influence on the economies of several countries.

Presently, coconut ranks as the fourth most extensive crop planted after oil palm, rubber and rice (Table 1). The rapid decline since the 1980's from 409,348 hectares to the current planted area of 98,533 hectares (DOA, 2014) has largely been attributed to crop conversion to oil palm which had become more lucrative since the advent of declining copra and cocoa prices. Figures $1 \mathrm{a}$ and $1 \mathrm{~b}$ illustrate the decline in coconut hectarage since 2000 and the respective production for the various years. The concomitant decline in production resulted in a severe shortage of coconuts to meet the local demand. Imports of coconuts in recent years have been between $70 \mathrm{M}-80 \mathrm{M}$ nuts per year (DOA, 2014).

Table 1. Total area under selected crops in Malaysia in 2012

\begin{tabular}{|c|c|}
\hline Crop & Hectarage \\
\hline Oil Palm & $5,076,929$ \\
\hline Rubber & $1,041,544$ \\
\hline Paddy & 692,000 \\
\hline Coconuts & 112,000 \\
\hline Cocoa & 21,710 \\
\hline Pineapple & 19,000 \\
\hline Pepper & 14,791 \\
\hline Coffee & 5,000 \\
\hline Sugarcane & 4,000 \\
\hline Tea & 3,000 \\
\hline Tobacco & 2,526 \\
\hline
\end{tabular}

Source: Cited in Statistics on Commodities 2012; pg 9. Ministry of Plantation Industries and Commodities.

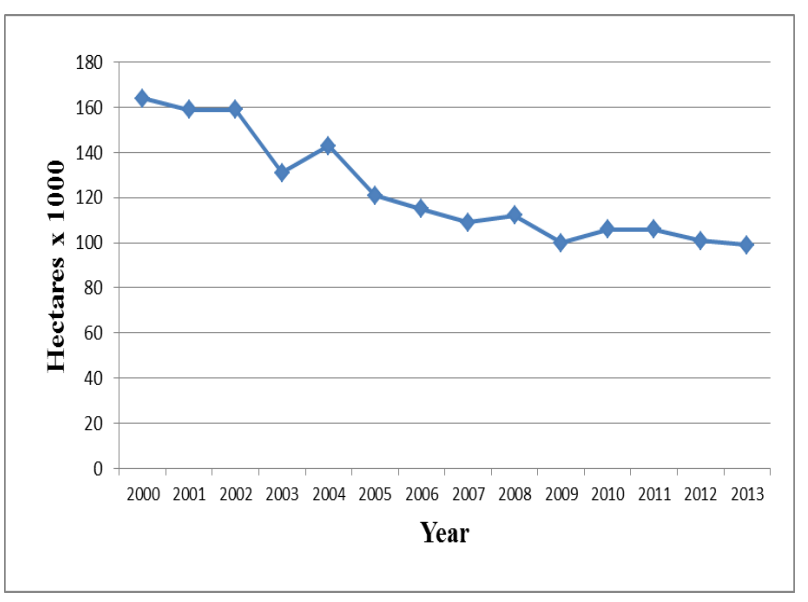

Figure 1a. Coconut Hectarage in Malaysia (Source: Department of Agriculture, Malaysia, 2014).

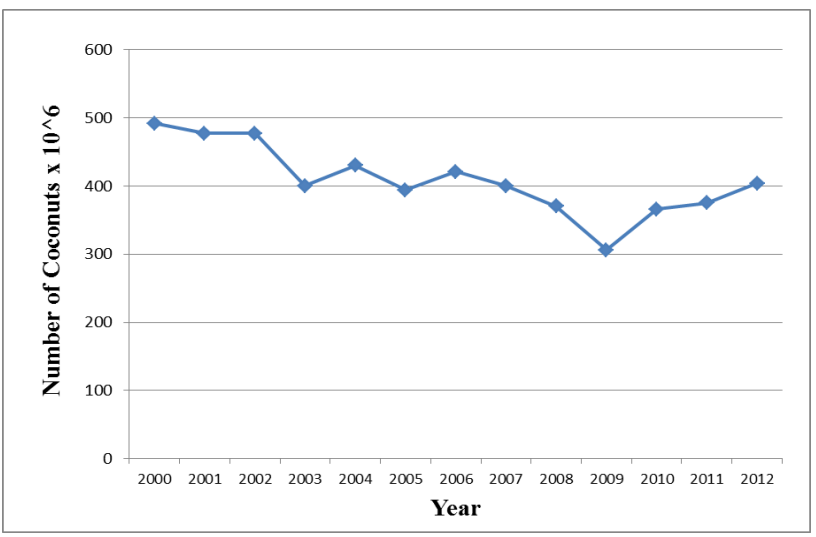

Figure 1b: Coconut Production in Malaysia (Source: Department of Agriculture, Malaysia, 2014).

Limitations in land availability for development of agricultural crops had spurred the momentum in breeding to increase production per hectare. The Malaysian government had envisaged to produce $700 \mathrm{M}$ nuts annually by 2015 through a revitalization programme. United Plantations Berhad with two coconut plantations totaling 3,000 hectares is currently the largest producer of coconuts in Malaysia, producing close to $80 \mathrm{M}$ nuts per year or equivalent to $20 \%$ of the country's production. The company has been pivotal in the success of the programme as it is the largest if not the sole supplier of superior hybrid seednut planting materials for the rehabilitation of the coconut smallholdings in the country. 
PB 121, locally called MAWA (Malayan Dwarf $\mathrm{x}$ West African Tall) was introduced for commercialization in the mid-1970. It was initially adopted to replace the tall coconuts in the cocoa-coconut plantations but declining prices and infestation by the cocoa pod borer prompted conversion to plantings of alternative crops such as oil palm. However, United Plantations Berhad maintained its philosophy of crop diversification by retaining its existent coconut hectarage. In line with this, the Research Department was tasked to improve productivity through the development of hybrids and seednut production for upgrading and replanting.

In the 1990's, MATAG (Malayan Dwarf x Tagnanan Tall) hybrid was introduced for commercial cultivation. MATAG was noted for its superiority against MAWA mainly in terms of copra yields per hectare which was approximately 18\% higher (Mukesh Sharma et. al., 2000). Its ease of de-husking for dry nut purposes (Mukesh Sharma et. al.), larger nuts size with higher water content and reduced husk thickness made the MATAG hybrid a more versatile variety in terms of suitability for both tender and dry nut.

Continuous efforts of the breeding team has produced several other high yielding varieties in the pipeline for commercialization, including the dwarf hybrids for the tender nut market with yield potentials exceeding 35,000 nuts per hectare per year. Other selection criteria such as disease tolerance (grey leaf blight etc.), lower height increment, sweeter and more flavorful water content as well as ease of seednut creation (increased hybrid success rate) are being emphasized in the pursuit of newer hybrids.

This paper provides an overview of some of the research efforts in generating coconut hybrids with an account of its commercial performance and seednut production.

\section{Materials and methods}

\section{Germplasm Conservation and Evaluation at UPB}

From the beginning of cultivation and research in UPB, coconut planting materials have been categorized into three main subgroups namely Talls, Dwarfs and Dwarf x Tall hybrids. UPB's current Tall and Dwarf coconut pure line cultivars is given in Table 2.

Germplasm collections planted in UPB were evaluated both in trials and commercial blocks from the early 1980's to present. Trials were laid out in a randomized complete block design (RCBD) and commercial blocks consisting approximately 150 palms per cultivar planted at two different locations within UPB estates. Germplasm conservation and progeny materials were strictly created through controlled pollination and raised separately to avoid contamination. Individual palms of respective populations were evaluated by yield recording and nut analysis from maturity. Yield recording was carried out once a month by counting and marking developed nuts on the palms. Minimum 30 nuts were selected from each cultivar for nut analysis using the standard nut analysis procedure from COGENT and IPGRI STANTECH manual. Subsequently, the computed cumulative data were subjected to basic statistics and SAS analysis to determine the effects of each treatment on individual parameters.

New generations of germplasm is created through selfing and sib-crossing once every ten years to avoid losses and evaluated for further selection purposes.

\section{Commercial Coconut Seed Garden at UPB}

The seed garden comes under the purview of the Research Department. It is mandated to ensure seedling requirement for the replanting programme of the company's coconut estates and the balance to be provided for the country's smallholders replanting programme coordinated by the Department of Agriculture, Ministry of Agriculture.

The seed garden with Malayan Dwarfs as the mother palms had been planted at a density of 252 palms per hectare over a 25 hectare stretch within an oil palm estate. The Tagnanan Tall which is currently the sole Tall parent planted over a total area of 20 hectares at a density of 140 palms per hectare in a coconut estate. 
Table 2. Coconut cultivars in United Plantations Berhad

\begin{tabular}{|c|c|c|c|c|c|}
\hline No. & Variety & Coconut Cultivar & Abbreviation & $\begin{array}{c}\text { Year of } \\
\text { Introduction }\end{array}$ & Source \\
\hline 1 & \multirow{6}{*}{ Tall } & Malayan Tall & MLT & 1912 & Indigenous \\
\hline 2 & & West African Tall & WAT & 1972 & $\begin{array}{l}\text { IRHO, Port Bouet, } \\
\text { Ivory Coast }\end{array}$ \\
\hline 3 & & Rennel Island Tall & RLT & 1974 & $\begin{array}{l}\text { IRHO, Port Bouet, } \\
\text { Ivory Coast }\end{array}$ \\
\hline 4 & & Tahiti Tall & THT & 1976 & $\begin{array}{l}\text { IRHO, Port Bouet, } \\
\text { Ivory Coast }\end{array}$ \\
\hline 5 & & Tagnanan Tall & TGT & 1979 & $\begin{array}{c}\text { Tagnanan Estate, Davao, } \\
\text { Philippines }\end{array}$ \\
\hline 6 & & Laguna Tall & LGT & 1980 & $\begin{array}{c}\text { Philippine Coconut } \\
\text { Authority, Davao, } \\
\text { Philippines }\end{array}$ \\
\hline 7 & \multirow{7}{*}{ Dwarf } & $\begin{array}{l}\text { Malayan Red } \\
\text { Dwarf }\end{array}$ & MRD & 1931 & Indigenous \\
\hline 8 & & $\begin{array}{l}\text { Malayan Yellow } \\
\text { Dwarf }\end{array}$ & MYD & 1931 & Indigenous \\
\hline 9 & & $\begin{array}{l}\text { Malayan Green } \\
\text { Dwarf }\end{array}$ & MGD & 1931 & Indigenous \\
\hline 10 & & Catigan Dwarf & CAD & 1980 & $\begin{array}{c}\text { Philippine Coconut } \\
\text { Authority }\end{array}$ \\
\hline 11 & & Tacunan Dwarf & TAD & 1980 & Davao \\
\hline 12 & & $\begin{array}{c}\text { Cameroon Red } \\
\text { Dwarf }\end{array}$ & CRD & 1980 & $\begin{array}{l}\text { IRHO, Port Bouet, } \\
\text { Ivory Coast }\end{array}$ \\
\hline 13 & & $\begin{array}{c}\text { Aromatic Green } \\
\text { Dwarf or 'Pandan' }\end{array}$ & AGD & $1991-2000$ & $\begin{array}{l}\text { DOA \& Commercial } \\
\text { Nurseries, Malaysia }\end{array}$ \\
\hline
\end{tabular}

Source: Sharma, M(2005)

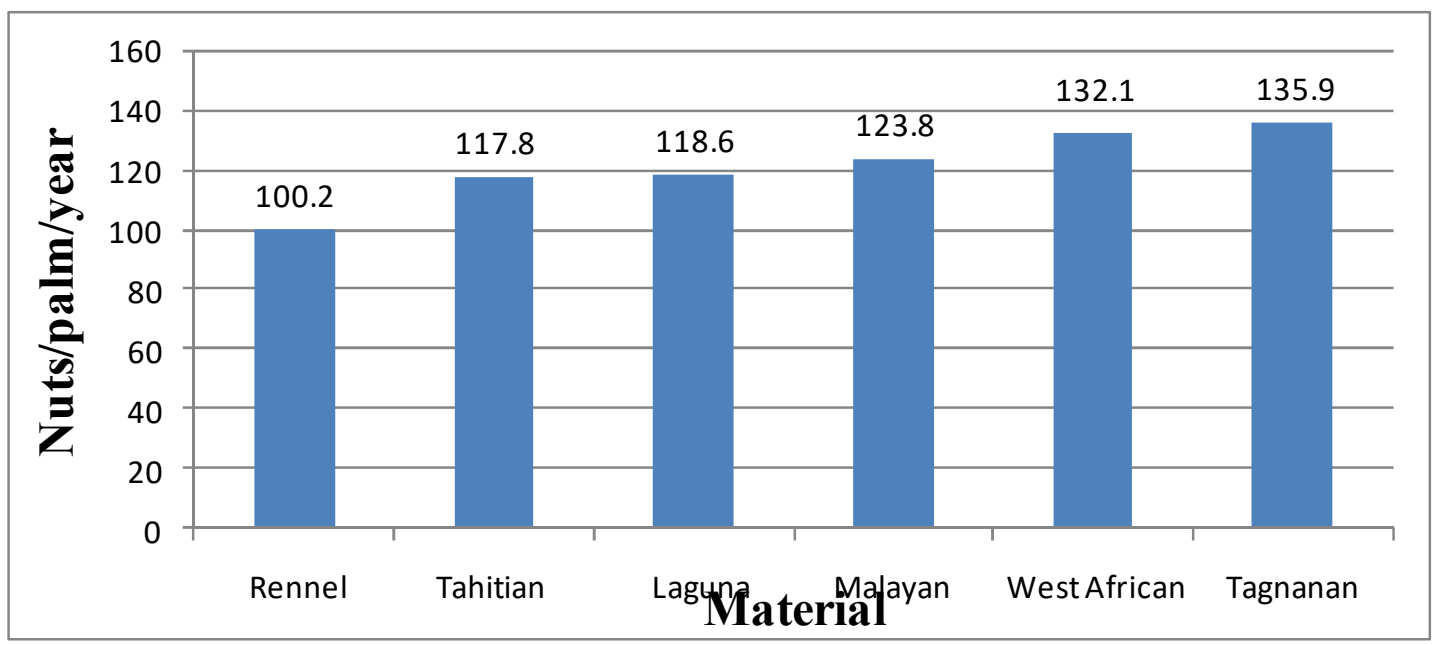

Figure 2. Mean nut number production for the Talls averaged over a 10 year period 
A sand bed nursery of 0.6 hectares with an overhead sprinkler system is maintained for raising the sown seednuts to 4 month old seedlings before it is dispatched to the estates or to the clients. The present capacity of the nursery is 110,000 saleable seedlings assuming culling rates of $50 \%$ due to various factors.

\section{Results and discussion}

\section{Evaluation of Tall Cultivars}

From the germplasm collection at United Plantations Berhad various tall materials were evaluated. Over a ten year period of evaluation, only the Tagnanan Tall and West African Tall had higher nut numbers than the Malayan Tall by $9.8 \%$ and $6.7 \%$ respectively (Figure 2 ).

\section{Evaluation of Tall $x$ Tall Cultivars}

Tall $\mathrm{x}$ Tall crosses were also evaluated (Figure 3) with the intention to select for more desirable nut traits. In terms of nut numbers, the crosses of West African Tall $\mathrm{x}$ Tagnanan Tall and West African Tall $x$ Laguna Tall had reasonably high nut numbers of 128 and 129 nuts per palm per year, respectively.

\section{Evaluation of Dwarf Cultivars}

Amongst those evaluated, the Aromatic Green Dwarf, Cameroon Red Dwarf and the Malayan Yellow Dwarf had high mean nut numbers ranging between 144 to 151 nuts per palm per year, respectively (Figure 4).

Chan (1983) reported planting of Malayan Dwarf coconuts in United Plantations Berhad as early as 1931 and reported yields of test plots of red, yellow and green dwarfs over a period of ten years with mean copra yields of 2148, 2451 and 2236 tonnes per hectare per year, respectively.

\section{Evaluation of Dwarf x Dwarf Cultivars}

Over a 10 year period of evaluation, Malayan Dwarf x Tacuna Dwarf had the lowest mean yields of 134 nuts per palm per year, whereas the rest of the combination crosses had mean yield ranging between 146 to 151 nuts per palm per year (Figure 5). Sharma, $M$ (2005) reported yield and vegetative characters of some of the dwarf and dwarf hybrids (Table 3).

\section{Evaluation of Dwarf x Tall Hybrids}

Amongst the crosses evaluated, five hybrids have potential to yield above 25,000 nuts per hectare per year viz. MAWA, MATAG, Cameroon $\mathrm{x}$ West African Tall, Tacuna $\mathrm{x}$ Laguna Tall, Tacuna $\mathrm{x}$ West African Tall, Tacuna x Tagnanan Tall and Malayan x Laguna Tall.

The challenge ahead is to develop newer hybrid crosses which can outyield the productivity of MAWA and MATAG and with favourable nut characteristics.

\section{The Commercial Coconut Seed Garden of United Plantations Berhad}

\section{Process sequence of coconut hybrid seednut production}

1. Regular collection of sufficient inflorescences for pollen processing from tall coconut garden. The pollen is mixed with talc powder in the ratio of 1:20.

2. Timely identification of inflorescence ready for emasculation in the dwarf parent seed garden is crucial. A slight overlook could result in fully mature inflorescences being missed, thus leading to such inflorescences blooming in the seed garden and causing high levels of self pollination. The identification of mature Malayan Dwarf inflorescences ready for processing is an acquired skill.

3. Removal of spadix sheath and emasculation.

Sheath covering the spadix is first removed by making a slit along the axis and splitting down to the peduncle. Sheath is cut at the base and removed. Spikelets are cut approximately three inches above the highest female button. Remaining male flower sacks are then picked out and discarded leaving the inflorescence completely emasculated.

4. Pollination of receptive female flowers.

Since anthesis of female flowers take place in flushes, pollination has to be carried out frequently, and thus large amounts of pollen are required. Pollen delivery is 
Cord 2014, $30(2)$

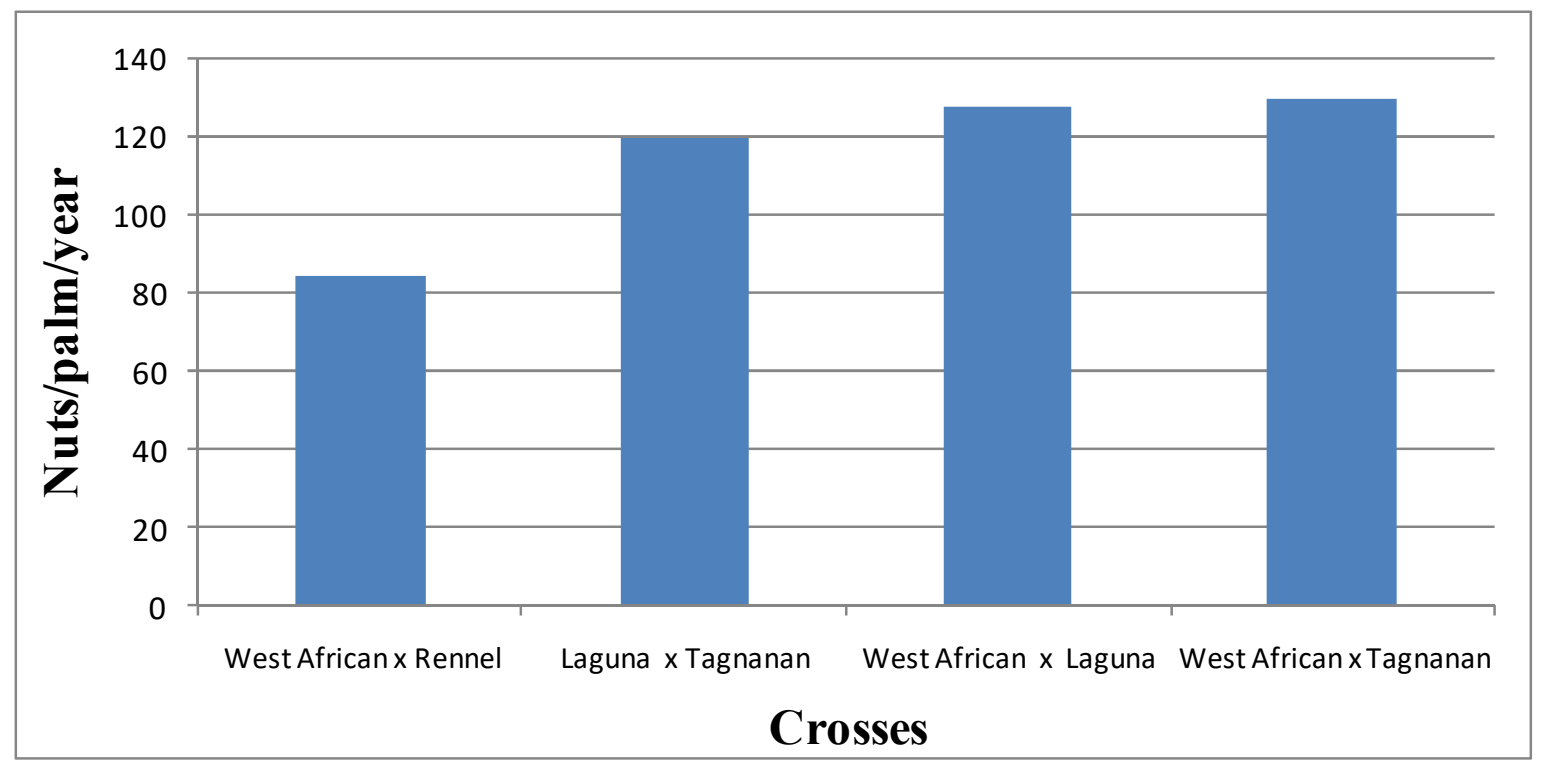

Figure 3. Mean nut number production by the Tall $\mathrm{x}$ Tall crosses, averaged over a ten year period

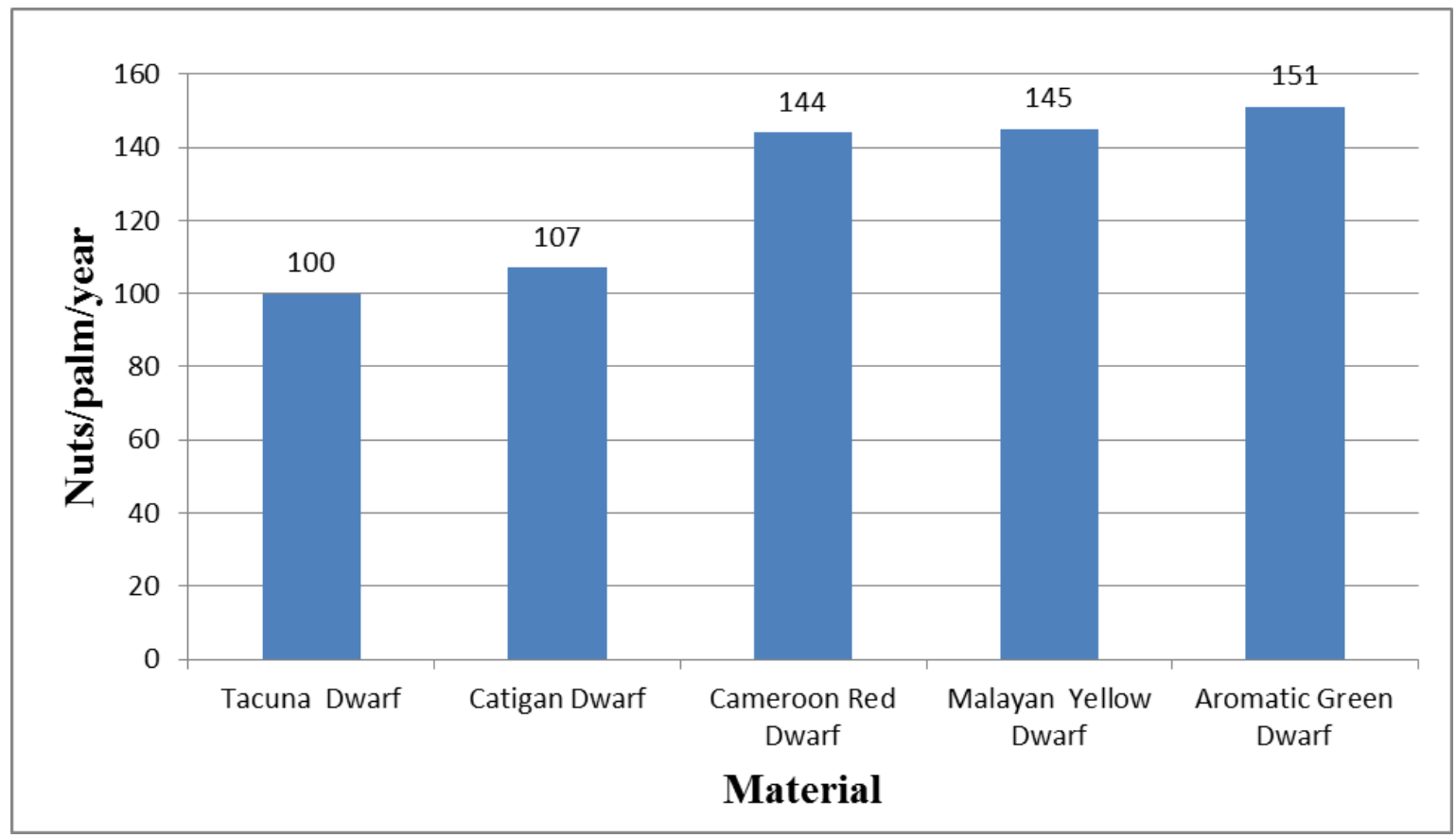

Figure 4. Mean nut number production of the Dwarfs, averaged over a ten year period 


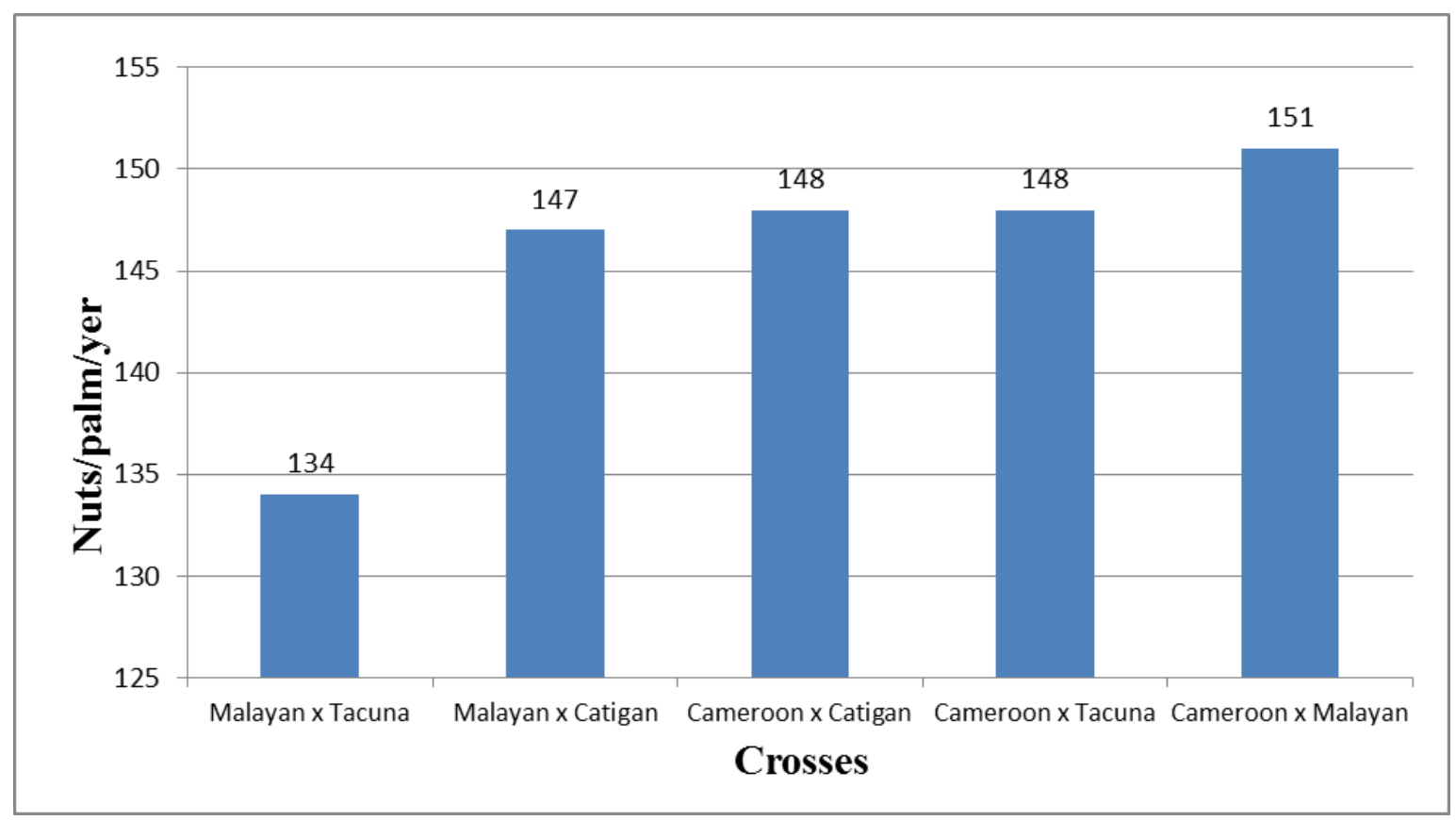

Figure 5. Mean nut number production of the Dwarf $x$ Dwarf crosses, averaged over a ten year period

Table 3. Yield and Vegetative Data Comparison of Four Dwarfs

\begin{tabular}{|c|c|c|c|c|}
\hline \multirow{2}{*}{ Components } & \multicolumn{5}{|c|}{ Variety } \\
\cline { 2 - 5 } & Tacuna & Catigan & MATA & MACA \\
\hline Yield Data (2003) & \multicolumn{5}{|c|}{} \\
\hline No. of Nuts/Palm & 100 & 108 & 110 & 115 \\
\hline No. of Bunches/Palm & 17 & 17.5 & 17.4 & 17.2 \\
\hline No. of Empty Bunches/Palm & 0.48 & 0.32 & 0.27 & 0.27 \\
\hline Dry Albumen/Palm (kg) & 25.5 & 22.8 & 24.1 & 27.6 \\
\hline Yield Data (3-Year Mean) & \multicolumn{5}{|c|}{} \\
\hline No. of Nuts/Palm & 98 & 96 & 114 & 118 \\
\hline No. of Bunches/Palm & 15.9 & 16.1 & 17.2 & 17.2 \\
\hline No. of Empty Bunches/Palm & 0.49 & 0.38 & 0.33 & 0.45 \\
\hline Dry Albumen/Palm (kg) & 28 & 20.3 & 25 & 28.4 \\
\hline Vegetative Data (2003) & \multicolumn{5}{|l}{} \\
\hline Rachis Length of Frond 14 (m) & 3.64 & 3.6 & 3.58 & 3.57 \\
\hline Frond Production & 17.5 & 17.4 & 17.4 & 17.4 \\
\hline Total Height (m) & 1.84 & 2.05 & 2.08 & 2.35 \\
\hline
\end{tabular}


administered using brushes for shorter palm and lance puffers for tall palms.

5. Harvesting of fully mature nuts. Mature nuts are collected throughout the year. Nuts are fully ripe at about the $10^{\text {th }}$ month and should preferable be collected from the palm when the nuts start to turn brown.

6. Nut germination and nursery maintenance. Mature nuts that have been harvested from the field are first sent to the nursery sand beds for germination. The sand beds should be located in an area which is of level ground, well drained with easy access and reliable supply of clean water. The sand beds are sized at $1.8 \mathrm{~m} \mathrm{x} 15.5 \mathrm{~m}$ each to hold 10 rows x 100 nuts / row. A $0.5 \mathrm{~m}$ wide path between beds is constructed to facilitate watering, inspection and removal of germinated nuts. Sandbeds may require fungicide and insecticide spraying to reduce fungal and insect pest incidences.

7. Monitoring and removal.

Seednuts take 4-6 weeks to show signs of germination. At this point it would be possible to determine the type of seedling that is formed, by observing the emerging growing point. All off types and abnormal seedlings are culled over the following 4 months.

8. Selection of Seedlings.

Stringent selection criteria are essential to ensure that only seedlings with normal, vigorous growth are transplanted. At United Plantations Berhad, seedlings manifesting the following traits are culled: stunted, choked, crinkled, poor vigour, twisted, narrow leaf, rolled leaf, distorted leaf, elongated, twins / triplets and pest damage.

In general, above $70 \%$ of the nuts sown into the sand bed germinate but only $30 \%$ $-50 \%$ of the nuts achieve marketability.

Depending on size of seed garden and nursery the requirement for labour force varies. An optimally operational seed nut unit with a capacity of 110,000 saleable hybrid nut involving operations such as pollination, emasculation and maintenance would require the following workforce:

\section{$\underline{\text { Seed Garden }}$}

1 manager of seed garden

2 field staff

4 workers for supervision

10 pollinators

10 emasculators

\section{Nursery}

1 supervisor

5 general workers

\section{For Pollen Collection}

1 supervisor

2 workers

\section{For Pollen Processing}

1 supervisor

2 workers

With an efficient team the following targets should be achievable:

Pollination : 500 palms per manday

Emasculation : 50 spikes per manday

Pollen collection : 40 inflorescences per manday Pollen processing: 600 grams dry pollen per manday

\section{Proportionate Production Cost of MATAG Seednut}

Table 4 gives the proportionate costs for the various activities involved in the production of 100,000 to 110,000 seednuts.

\section{Conclusion}

United Plantations Berhad is currently aiding in the nationwide replanting with the provision of the MATAG planting material. With a larger nut leading to increased water volume, the MATAG variety proved to be more versatile as both a fresh (tender nut) and dry nut. Nut analysis carried out on the MATAG hybrid shows an average water content of $0.28 \mathrm{kgs}$ $(20.10 \%)$ with a sucrose content of $5.76 \%$. 
Table 4. Proportionate Costing of Seednut Production in United Plantations Berhad

\begin{tabular}{lc}
\multicolumn{1}{c}{ Activity } & Proportion (\%) \\
\hline Emasculation and Pollination & 27.4 \\
Pollen Collection and Processing & 11.9 \\
Harvesting and Transporting of Seednuts to Nursery & 4.0 \\
Germination on Sandbeds & 11.9 \\
Compensation of Estate for Loss in Productivity & 15.8 \\
Pest and Disease Control & \\
(Chemical and Labour) & 4.0 \\
Field Maintenance & \\
(Fertilisers, Weedicides and General Upkeep) & \\
Supervision Cost & 4.0 \\
(Staff and Executive) & \\
Miscellaneous Expenses & 2.0 \\
General Charges & \\
Equipment and Vehicle Maintenance & 2.0 \\
\hline
\end{tabular}

Table 5. Nut Analysis of MATAG and New Hybrid

\begin{tabular}{|c|c|c|c|}
\hline \multirow{2}{*}{\multicolumn{2}{|c|}{ COMPONENTS }} & \multicolumn{2}{|c|}{ HYBRIDS } \\
\hline & & MATAG & NEW HYBRID \\
\hline \multicolumn{2}{|c|}{ NUT SIZE (L) (CM) } & 36.18 & 38.04 \\
\hline \multicolumn{2}{|c|}{ NUT SIZE (D) (CM) } & 38.08 & 38.41 \\
\hline \multirow{9}{*}{ PER FRUIT (KGS) } & FRUIT & 1.37 & 1.25 \\
\hline & NUT & 0.82 & 0.89 \\
\hline & HUSK & 0.55 & 0.36 \\
\hline & WATER & 0.28 & 0.28 \\
\hline & ALBUSHELL & 0.54 & 0.62 \\
\hline & F.ALBUMEN & 0.32 & 0.40 \\
\hline & SHELL & 0.22 & 0.21 \\
\hline & D.ALBUMEN & 0.14 & 0.22 \\
\hline & OIL & 0.08 & 0.10 \\
\hline \multirow{8}{*}{ PERCENTAGE FRUIT (\%) } & NUT & 59.70 & 71.20 \\
\hline & HUSK & 40.30 & 28.80 \\
\hline & WATER & 20.10 & 21.60 \\
\hline & ALBUSHELL & 39.60 & 49.60 \\
\hline & F.ALBUMEN & 23.50 & 32.50 \\
\hline & SHELL & 16.00 & 17.10 \\
\hline & D.ALBUMEN & 10.30 & 17.70 \\
\hline & OIL & 5.80 & 8.00 \\
\hline$\%$ OIL & D.ALBUMEN & 65.70 & 64.80 \\
\hline SUCROSE (\%) & WATER & 5.76 & 5.56 \\
\hline
\end{tabular}


A newer hybrid is in the pipeline of production with the potential of replacing or complementing the MATAG. With slightly superior nut traits of increased nut size and water content, fresh and dry albumen content, and net oil production, the new hybrid is expected to be more versatile than the MATAG (Table 5). Extensive analysis and research will continue in assessing the new hybrid before commercialization.

\section{Acknowledgement}

The authors convey their appreciation and thanks to Messrs United Plantation Berhad for permission to present the paper and also to the organizing committee of the $46^{\text {th }}$ APCC conference for availing us the opportunity.

\section{References}

Chan, E. 1979 - Growth and early yield performance of Malayan Dwarf x Tall coconut hybrids on the coastal clays of Peninsular Malaysia. Oleagineux, Vol. 34, No. 21979

Mukesh Sharma, Gurmit Singh, C.V. Rajah Padman \& Toh Tai San 2000 - MAWA and MATAG: Two high yielding hybrids for the revitalisation of the Malaysian coconut industry.

Sharma, M. 2005 - Results of coconut hybrid trials by United Plantations Berhad, Malaysia. $4^{\text {th }}$ National Seed Symposium at IOI Palm Garden Hotel, Putrajaya, June 2006.

DOA 2004 - Department of Agriculture. Personal Communication. 